\title{
Expression of integrins on human choroidal neovascular membranes
}

\author{
Jing Cui • David Maberley • Arif Samad • Patrick Ma • \\ Allison Ning • Joanne A. Matsubara • Peter Baciu
}

Received: 12 June 2008 / Accepted: 28 January 2009 /Published online: 24 February 2009

(C) The Author(s) 2009. This article is published with open access at Springerlink.com

Keywords Choroidal neovascularization · Integrins · Immunohistochemistry

\section{Introduction}

Most of the focus in choroidal and retinal angiogenesis centers on the regulation of endothelial function by soluble factors. Less well-understood, but nevertheless significant, is the regulation of endothelial cell function by its insoluble microenvironment, the extracellular matrix (ECM). Endothelial interaction with the ECM occurs primarily through cell surface receptors belonging to the integrin family that relay information from the ECM to the intracellular signaling machinery.

The integrin family is composed of 24 heterodimeric type I transmembrane cell surface receptors containing an alpha and a beta subunit. To date, there are known to be 18 alpha and eight beta subunits [1]. Alpha subunits are designated 1-11, iib, v, D, E, L, M, and X. Beta subunits have designations of $1-8$. The heterodimeric receptor is

J. Cui · D. Maberley $\cdot$ P. Ma • A. Ning · J. A. Matsubara Department of Ophthalmology and Visual Sciences, University of British Columbia,

Vancouver, BC, Canada

\author{
A. Samad \\ Department of Ophthalmology, Dalhousie University, \\ Halifax, NS, Canada \\ P. Baciu $(\square)$ \\ Allergan Inc., \\ Irvine, CA, USA \\ e-mail: Baciu_Peter@Allergan.com
}

designated through identification of the corresponding alpha and beta subunits, e.g., $\alpha$ iib $\beta 3$ designates the platelet integrin. The ECM specificity of individual integrin family members covers a broad spectrum of selectivity as exemplified by the restricted specificity of the $\alpha 5 \beta 1$ integrin for only fibronectin and the promiscuous binding of the $\alpha v \beta 3$ to a diverse set of ECM [2]. Even with this disparity in matrix selectivity, integrin family members can be categorized based on the subset of matrices recognized and cell type expression patterns. The four categories consist of integrins that preferentially bind collagen, laminin, or ECM containing an arg-gly-asp (RGD) tripeptide motif and integrins which are primarily leukocytespecific receptors [1, 2]. The ability of a number of integrins to recognize the same primary matrix implies that there is potential overlap among family members. While there clearly can be some degree of functional compensation, as seen in the ability of the $\alpha v \beta 3$ integrin to supplement fibronectin matrix assembly in the absence of $\alpha 5 \beta 1$ integrin [3], this functional compensation is incomplete, implying that each family member is likely to have a crucial functional role within a given biological process.

The functional activity of integrin family members can be typically viewed as having a permissive role in providing adhesive function; however, in some cases, this role may be regulatory rather than permissive in nature, as in the case of the $\alpha v \beta 3$ integrin, which is believed to modulate neovascular response [4]. Furthermore, the functional activity may also depend on the presence of other integrin family members, which may suppress function via a mechanism of transmodulation known as transdominance $[5,6]$. It is clear that in order to gain a better understanding of how cell adhesion, and especially integrins, regulate a biological process, it is essential to 
understand the repertoire of integrins involved and their expression relative to disease progression.

During neovascularization, several integrin family members have been implicated in regulating endothelial cell function, including $\alpha 1 \beta 1, \alpha 2 \beta 1, \alpha 5 \beta 1, \alpha v \beta 3$, and $\alpha \mathrm{v} \beta 5$ [7]. In ocular neovascular membranes (POHS, idiopathic, choroidal neovascular $[\mathrm{CNV}], \mathrm{PVR}$, and PDR), integrin expression has been studied in only a few instances [8-10], with focus on either a subset of receptors $[8,9]$ or the examination of a broad range of integrin subunits in a small number of membranes [10]. To obtain a more comprehensive understanding of integrin family member expression in neovascular progression, we examined the expression of $\alpha 1 \beta 1, \alpha 2 \beta 1, \alpha 5 \beta 1, \alpha \mathrm{v} \beta 3$, and $\alpha \mathrm{v} \beta 5$ integrins in surgically removed subretinal membranes with an emphasis on identifying integrins expressed primarily on endothelial cells.

In the present study, surgically removed human $\mathrm{CNV}$ membranes, for which the patient histories and disease progression are known, were characterized for integrin expression relative to the endothelial markers CD31 and VWF. Consistent with known neovascular responses, endothelial staining correlated well with patient histories, with endothelial staining in active and mid stage disease, but little or no staining of endothelial cells in tissues from late stage and fibrotic membranes. Integrin staining was primarily seen in early and mid stage where $\alpha v \beta 3, \alpha 1 \beta 1, \alpha 2 \beta 1$, and $\alpha 5 \beta 1$ staining colocalized with endothelial cells. No correlation between $\alpha v \beta 5$ staining and endothelial cells was observed.

\section{Materials and methods}

Tissue preparation and staging

Twenty-four CNV membranes, at various stages of CNV, were collected from eyes via vitreoretinal surgery. The membranes were set in molds using OCT compound (Tissue-Tek, Torrance, CA, USA) and stored at $-80^{\circ} \mathrm{C}$ prior to sectioning. Membranes were serially sectioned using a Frigocut $2800 \mathrm{~N}$ Cryostat (Reichert-Jung, Chicago, IL, USA) into $6 \mu \mathrm{m}$ sections and mounted onto frosted glass slides (using a process that electrostatically adheres frozen tissue sections and cytological specimens to the slide; Fisher Scientific, Ottawa, $\mathrm{ON}$, Canada). Slides were then stored at $-20^{\circ} \mathrm{C}$ until immunohistochemical processing was conducted. All tissue collection was conducted according to The University of British Columbia (UBC) Clinical Research Ethics Board (CREB)-approved study protocol. The UBC CREB policies comply with the Tri-Council Policy and the Good Clinical Practice Guidelines, which have their origins in the ethical principles set out in the Declaration of Helsinki. Written informed consent was obtained from patients. Fluorescent angiographic findings were used in conjunction with clinical findings to stage the lesions. Clinical categorization of lesions was based on lesion size and the presence or absence of fibrosis. Lesions less than four disc areas in total size with no clinical evidence of fibrosis were classified as "active." Lesions greater than four disc areas with no fibrosis were considered "mid stage." Lesions with subretinal fibrosis of less than $50 \%$ of the entire lesion size were classified as "late." "Fibrotic" lesions were composed of greater than $50 \%$ fibrosis.

\section{Immunohistochemical staining}

A double immunohistochemical staining procedure was used to identify the presence and colocalization of integrins and endothelial cells. Slides were initially air-dried for $20 \mathrm{~min}$ at room temperature. The sections on the slides were then circled with a PAP pen (Daido Sangyo, Tokyo, Japan) and fixed in acetone for $10 \mathrm{~min}$, followed by rinsing in phosphate buffer (PBS) and 0.1\% Triton X-100 (Sigma) for $5 \mathrm{~min}$. The sections were treated with $0.3 \% \mathrm{H}_{2} \mathrm{O}_{2}$ for $15 \mathrm{~min}$, and then blocked in blocking buffer (PBS pH 7.4, $0.1 \%$ Triton X-100, and 5\% normal horse serum [Vector $\mathrm{Lab}$ ]) for $20 \mathrm{~min}$. Sections were incubated with primary antibodies diluted in probing buffer composed of $0.1 \%$ Triton X-100 in PBS for $1 \mathrm{~h}$. All the anti-integrin antibodies used were mouse monoclonal or polyclonal rabbit antibodies and can be viewed in Table 1. Primary antibodies to identify endothelium used included polyclonal rabbit antiVon Willebrand factor (VWF) (Chemicon, Temecula, CA, USA) or monoclonal mouse anti-CD31, clone JC70A (DakoCytomation, Denmark). Anti-integrin integrin antibodies were obtained from Chemicon (Temecula, CA, USA) and included rabbit polyclonal antihuman integrin $\beta 3$, AB1932 (1:100) - AB1932 recognizes all potential heterodimers containing the $\beta 3$ subunit, including $\alpha \mathrm{v} \beta 3$ and $\alpha$ iib $\beta 3$, rabbit polyclonal antihuman integrin $\alpha 1$ (1:100), rabbit polyclonal antihuman integrin $\alpha 2$ AB1936 (1:100), rabbit polyclonal antihuman integrin $\alpha 5$ AB1928 $(1: 100)$ and mouse monoclonal antihuman integrin $\alpha \mathrm{v} \beta 3$, clone: LM609 (1:100), mouse monoclonal antihuman integrin $\alpha \mathrm{v} \beta_{5}$ clone P1F6 (1:500). For the double staining, mouse antihuman $\alpha \mathrm{v} \beta 3$ and $\alpha \mathrm{v} \beta 5$ were paired with the polyclonal rabbit anti-VWF (1:200); rabbit antihuman integrin $\beta 3, \alpha 1, \alpha 2$, and $\alpha 5$ were paired with monoclonal mouse antihuman CD31 (1:200). After incubation at room temperature for $2 \mathrm{~h}$ with the primary antibodies, the slides were washed three times over $15 \mathrm{~min}$ with fresh PBS. This was followed by the application of fluorescent secondary antibodies diluted 1:400 in PBS for 30 min. The secondary antibodies used were antirabbit Alexa-488 (Molecular Probes, Eugene, OR, USA), antimouse Alexa-488 (Molecular Probes, Eugene, OR, USA), and antimouse $\mathrm{Cy} 3$ (Jackson Immunoresearch, West Grave, PA, USA). After $30 \mathrm{~min}$, the slides were washed three times over $15 \mathrm{~min}$ 
Table 1 Summary of integrin antibodies and ligands used in the study

\begin{tabular}{|c|c|c|c|c|c|c|}
\hline Antigen & $\begin{array}{l}\text { Dimer } \\
\text { (s) }\end{array}$ & Type & Possible ligand(s) & $\begin{array}{l}\text { Types of cell(s) } \\
\text { expressing integrin }\end{array}$ & Concentrations & $\begin{array}{l}\text { Source and } \\
\text { catalog no. }\end{array}$ \\
\hline$\alpha 1$ & $\alpha 1 \beta 1$ & Polyclonal & Collagen, laminin & $\begin{array}{l}\text { Activated T cells, monocytes, } \\
\text { melanoma cells, smooth } \\
\text { muscles cells }\end{array}$ & $1: 100$ & $\begin{array}{l}\text { Chemicon, } \\
\text { Temecula; } \\
\text { CA AB1934 }\end{array}$ \\
\hline$\alpha 2$ & $\alpha 2 \beta 1$ & Polyclonal & $\begin{array}{l}\text { Collagen, laminin, } \\
\text { thrombospondin }\end{array}$ & $\begin{array}{l}\text { B and T lymphocytes, platelets, } \\
\text { fibroblasts, endothelial cells, } \\
\text { melanoma cells }\end{array}$ & $1: 100$ & $\begin{array}{l}\text { Chemicon, } \\
\text { Temecula; } \\
\text { CA AB1936 }\end{array}$ \\
\hline$\alpha 5$ & $\alpha 5 \beta 1$ & Polyclonal & Fibronectin & $\begin{array}{l}\text { Memory T cells, monocytes, } \\
\text { platelets, fibroblasts }\end{array}$ & $1: 100$ & $\begin{array}{l}\text { Chemicon, } \\
\text { Temecula; } \\
\text { CA AB1928 }\end{array}$ \\
\hline$\beta 3$ & $\begin{array}{l}\alpha \mathrm{v} \beta 3 \\
\text { and } \\
\alpha \operatorname{IIb} \beta 3\end{array}$ & Polyclonal & $\begin{array}{l}\text { Vitronectin, fibrinogen, VWF, } \\
\text { fibronectin, OP, BSPI, MFG- } \\
\text { E8, thrombospondin }\end{array}$ & $\begin{array}{l}\alpha \mathrm{v} \beta 3 \text { : endothelial cells, } \\
\text { platelets, monocytes; } \alpha \operatorname{IIb} \beta 3 \text { : } \\
\text { platelets }\end{array}$ & $1: 100$ & $\begin{array}{l}\text { Chemicon, } \\
\text { Temecula; } \\
\text { CA AB1932 }\end{array}$ \\
\hline$\alpha \mathrm{v} \beta 3$ & $\alpha v \beta 3$ & Monoclonal & $\begin{array}{l}\text { Vitronectin, fibrinogen, VWF, } \\
\text { fibronectin, OP, BSPI, MFG- } \\
\text { E8, thrombospondin }\end{array}$ & $\begin{array}{l}\alpha \mathrm{v} \beta 3 \text { : endothelial cells, } \\
\text { monocytes }\end{array}$ & $1: 100$ & $\begin{array}{l}\text { Chemicon, } \\
\text { Temecula; } \\
\text { CA } \\
\text { MAB1976 }\end{array}$ \\
\hline$\beta 5$ & $\alpha v \beta 5$ & Polyclonal & Vitronectin, MFG-E8 fibronectin & $\begin{array}{l}\text { Hepatoma cells, fibroblasts, } \\
\text { carcinoma cells }\end{array}$ & $1: 100$ & $\begin{array}{l}\text { Chemicon, } \\
\text { Temecula; } \\
\text { CA AB1928 }\end{array}$ \\
\hline$\beta 5$ & $\alpha v \beta 5$ & Monoclonal & Vitronectin, MFG-E8 fibronectin & $\begin{array}{l}\text { Hepatoma cells, fibroblasts, } \\
\text { carcinoma cells }\end{array}$ & $1: 500$ & $\begin{array}{l}\text { Chemicon, } \\
\text { Temecula; } \\
\text { CA } \\
\text { MAB1961 }\end{array}$ \\
\hline
\end{tabular}

$E C M$ extracellular matrix, $V W F$ Von Willebrand factor, $O P$ osteopontin, $B S P I$ bone sialoprotein 1 , Tsp thrombospondin, $M F G-E 8$ milk fat globule-EGF 8 (see Humphries et al. [2] for a more detailed list on all known integrins)

with fresh PBS. Stained slides were mounted using SlowFade (Molecular Probes, Eugene, ON, USA). Positive controls were set up using tonsil tissue. Negative controls were designed using tonsil tissue and $\mathrm{CNV}$ membranes with either one or both primary antibodies removed.

\section{Histology}

Several sections from each membrane were also stained for hematoxylin and eosin to allow bright field visualization of the cellular content and endogenous pigment and to compare with immunohistochemical staining. Briefly, the sections were stained with hematoxylin for $4 \mathrm{~min}$, rinsed in running tap water, and then dipped in $0.3 \%$ acid alcohol. This was followed by the application of eosin for $2 \mathrm{~min}$. The slides were dehydrated and mounted.

\section{Analysis}

CNV sections were analyzed using a Zeiss Inverted Axiovert 200M Confocal Laser-scanning Microscope (Zeiss-LSM 510 META). Random fields of the sections were imaged at $\times 20$ and $\times 40$ magnifications. The sections were scanned with laser wavelengths of 488 and $633 \mathrm{~nm}$.
The gain was adjusted for each wavelength to ensure minimal crosstalk. Absence of crosstalk in double-stained tissue was verified by analysis of negative controls in which one or both primary antibodies were absent. For each tissue, three independent staining and analysis procedures were conducted. The analysis was conducted by examination of five random fields per tissue section and the average score per field determined. Classification of staining was based on the level of observed fluorescence. If the field contained ten or more cells positively stained for antigens, it was classified as " +++ " indicating strong expression. If the field had six to ten cells positively stained for antigens, it was classified as "++", while a field with one to five positively stained cells were classified as "+." Both "++" and "+" indicated moderate fluorescence. If the field exhibited no fluorescence, it was classified as "-."

\section{Results}

Tissue sections

Figure 1 shows a representative bright field visualization of an active CNV membrane stained with hematoxylin and 
eosin. Note the presence of endogenous pigment. However, vascular structures were not clearly identifiable using bright field microscopy and were subsequently identified by staining for endothelial cells using CD31 and VWF. Immunofluorescent analysis excluded pigmented regions which autofluoresce.

Presence of endothelial staining relative to disease progression

Endothelial markers CD31 and VWF stained strongly to moderately in active and mid stage CNV membranes and mildly in late stage, with no staining in fibrotic tissues (Table 2). These data suggest that active neovascular response is present in the early and mid stages, while vessel regression is likely occurring in late stage, with completely avascular tissue within fibrotic membranes.

\section{Expression of integrin $\beta 3$ in $\mathrm{CNV}$ membranes}

Immunostaining for $\beta 3$ integrin recognizes both the $\alpha v \beta 3$ and $\alpha$ iib $\beta 3$ integrin heterodimers, which are primarily associated with endothelial and platelet cells, respectively. Mild labeling of integrin $\beta 3$ was seen in 11 out of the 12 CNV membranes $(92 \%, N=12)$ at active and mid stage (Table 2). Of the 11 tissues that expressed $\beta 3$ integrin in CNV membranes, ten $(83 \%)$ demonstrated colocalization with endothelial cells (Fig. 2a-c). Late and fibrotic stage $\mathrm{CNV}$ membranes were negative for integrin $\beta 3(N=12)$.

Expression of integrin $\alpha \mathrm{v} \beta 3$ in $\mathrm{CNV}$ membranes

Mild to moderate labeling of $\alpha \mathrm{v} \beta 3$ heterodimer was seen in $80 \%(N=5)$ of the $\mathrm{CNV}$ membranes characterized as active. Within positively staining membranes, $\alpha \mathrm{v} \beta 3$ exclusively colocalized with the endothelial cell-specific marker, VWF

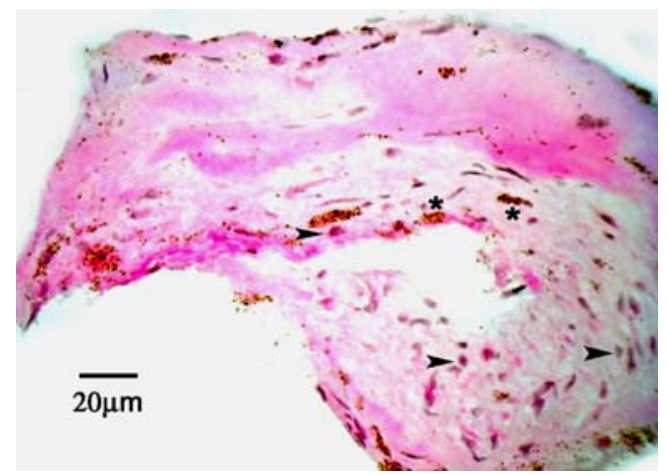

Fig. 1 Light micrograph of a cryostat section $(6 \mu \mathrm{m})$ taken from an active CNV membrane obtained during vitrectomy, stained with hematoxylin and eosin. Note several cell nuclei (purple hematoxylin). Arrowheads point to cell profiles that contain few pigment granules. Some areas of tissue contain dense pigment deposits (asterisk), which were not analyzed due to autofluorescence. Scale bar $=20 \mu \mathrm{m}$
(Fig. $2 \mathrm{~d}-\mathrm{f}$ ). In mid and late stage membranes $(N=12), 67 \%$ expressed $\alpha \mathrm{v} \beta 3$, although expression was not restricted to endothelial cells alone, with staining observed outside of positively staining endothelial cells. Membranes at fibrosis stage were negative for both $\alpha \mathrm{v} \beta 3$ and endothelial cells.

Expression of integrin $\alpha 1, \alpha 2$, and $\alpha \mathrm{v} \beta 5$ in $\mathrm{CNV}$ membranes

Staining for $\alpha 1, \alpha 2$, and $\alpha \mathrm{v} \beta 5$ was observed in early to late stage tissues, with $\alpha 1$ and $\alpha 2$ primarily seen in early stage tissues (Table 2). Within the early stage tissues, only $50 \%$ of the membranes showed $\alpha 1$ and $\alpha 2$ staining colocalizing with endothelial cells (Fig. 2g-1). $\alpha \mathrm{v} \beta 5$ staining was more pronounced in late stage tissues than that observed in early and mid stage tissues. Eighty-three percent of CNV membranes characterized as mid to late stage expressed $\alpha v \beta 5(N=12)$. Colocalization of $\alpha v \beta 5$ with endothelial staining occurred in only a single tissue sample from a patient with presumed ocular histoplasmosis (Fig. $2 \mathrm{~m}-\mathrm{o}$ ). Fibrotic membranes $(N=7)$ were negative for $\alpha 1, \alpha 2$, and $\alpha v \beta 5$ integrins.

\section{Expression of integrin $\alpha 5$ and in $\mathrm{CNV}$ membranes}

Immunostaining for $\alpha 5$ integrin was seen in early and mid stage membranes, with $80 \%$ of active stage CNV samples $(N=5)$ and $57 \%(N=7)$ mid stage samples showing positive $\alpha 5$ staining. Fifty percent of the membranes in both active and mid stages demonstrated colocalization with endothelial cell staining (Table 2, Fig. 2p-r). Immunostaining for $\alpha 5$ integrin was negative in late and fibrotic stages.

\section{Discussion}

The present study examined the correlation between the expression of cell adhesion receptors on endothelial cells with disease progression in subretinal neovascular membranes. The study was conducted by analyzing immunostaining in surgically obtained membranes with a clinically defined diagnosis. Endothelial staining correlated with the clinical diagnosis and known disease progression, with pronounced staining in early and mid stage tissues, decreasing staining in late stage, and absence in fibrotic membranes. Within active stage membranes, positive staining for $\alpha v \beta 3, \alpha 1 \beta 1, \alpha 2 \beta 1$, and $\alpha 5 \beta 1$ integrin family members colocalizing with endothelial cells was observed, although, $\alpha 1 \beta 1, \alpha 2 \beta 1$, and $\alpha 5 \beta 1$ staining was not exclusive to endothelial cells. Expression of $\alpha v \beta 5$ integrin did not colocalize with endothelial cells and was present only in the subset of membranes characterized as active. In mid stage membranes, a reduction in the presence of 
Table 2 Summary of membrane staining patterns for endothelial cells and integrins in membranes characterized as early, mid, late, and fibrotic stages of $\mathrm{CNV}$

\begin{tabular}{|c|c|c|c|c|c|c|c|c|c|c|c|}
\hline \multirow[t]{2}{*}{ Number } & \multirow[t]{2}{*}{ Cause of surgery } & \multirow[t]{2}{*}{ Age (years) } & \multirow[t]{2}{*}{ Sex } & \multirow[t]{2}{*}{ Stage } & \multirow[t]{2}{*}{ Endothelial staining } & \multicolumn{6}{|c|}{ Integrin staining/colocalization with endothelium } \\
\hline & & & & & & $\beta 3$ & $\alpha v \beta 3$ & $\alpha v \beta 5$ & $\alpha 1$ & $\alpha 2$ & $\alpha 5$ \\
\hline 1 & AMD & 74 & M & Active & +++ & $+/+$ & $+/+$ & $-1-$ & $+/+$ & $+/+$ & $+/+$ \\
\hline 2 & AMD & 89 & $\mathrm{~F}$ & Active & +++ & $+/+$ & $-1-$ & $+/-$ & $+/-$ & $+/+^{\mathrm{a}}$ & $-1-$ \\
\hline 3 & AMD & 69 & M & Active & +++ & $+/+$ & $+/+$ & $+/-$ & $+/-$ & $+/-$ & $+/-$ \\
\hline 4 & AMD & 81 & $\mathrm{~F}$ & Active & +++ & $+/+^{\mathrm{a}}$ & +/+ & $-1-$ & $+/+$ & $+/-^{\mathrm{a}}$ & $+/-$ \\
\hline 5 & Idiopathic & 13 & $\mathrm{~F}$ & Active & +++ & $+/+^{\mathrm{a}}$ & $++/++$ & $-1-$ & $+/+^{\mathrm{a}}$ & $++/+$ & $+/+$ \\
\hline 6 & AMD & 74 & $\mathrm{M}$ & Mid & ++ & $+/+$ & $-/-$ & $+/-$ & $+/-$ & $-/-$ & $+/+$ \\
\hline 7 & AMD & 60 & $\mathrm{~F}$ & Mid & ++ & $+/-$ & $+/+^{\mathrm{a}}$ & $+/-^{\mathrm{a}}$ & $-/-^{\mathrm{a}}$ & $-/-^{\mathrm{a}}$ & $+/-$ \\
\hline 8 & POHS & 15 & M & Mid & ++ & $+/+$ & $+/+$ & $+/+^{\mathrm{a}}$ & $-/-^{\mathrm{a}}$ & $-1-$ & $+/+$ \\
\hline 9 & Idiopathic CNV & 41 & M & Mid & ++ & $-/-$ & $+/+^{\mathrm{a}}$ & $+/-^{a}$ & $-/-$ & $-1-$ & $+/-$ \\
\hline 10 & AMD & 67 & $\mathrm{~F}$ & Mid & ++ & $+/+^{\mathrm{a}}$ & $-/-$ & $+/-$ & $-/-^{\mathrm{a}}$ & $-/-^{a}$ & $-1-$ \\
\hline 11 & AMD & 81 & $\mathrm{~F}$ & Mid & + & $+/+^{\mathrm{a}}$ & $+/-$ & $+/-^{\mathrm{a}}$ & $--^{\mathrm{a}}$ & $--^{\mathrm{a}}$ & $-1-$ \\
\hline 12 & Idiopathic CNV & 27 & $\mathrm{~F}$ & Mid & + & $+/+^{\mathrm{a}}$ & $+/-$ & $+/-^{\mathrm{a}}$ & $-/-$ & $-1-$ & $-1-$ \\
\hline 13 & AMD & 67 & M & Late & + & $-1-$ & $+/-^{a}$ & $+/-$ & $-1-$ & $-1-$ & $-1-$ \\
\hline 14 & POHS CNV & 36 & $\mathrm{~F}$ & Late & + & $-1-$ & $+/-$ & $+/-$ & $-1-$ & $-1-$ & $-1-$ \\
\hline 15 & Multifocal CNV & 33 & $\mathrm{~F}$ & Late & + & $-1-$ & $+/-$ & $+/-$ & $-/^{\mathrm{a}}$ & $-1-$ & $-1-$ \\
\hline 16 & Idiopathic CNV & 42 & $\mathrm{~F}$ & Late & + & $-/-^{\mathrm{a}}$ & $-/-$ & $-1-$ & $-/-^{\mathrm{a}}$ & $-1-$ & $-1-$ \\
\hline 17 & Idiopathic CNV & 29 & $\mathrm{~F}$ & Late & - & $--^{\mathrm{a}}$ & $-1-$ & $-/^{\mathrm{a}}$ & $-/^{\mathrm{a}}$ & $-/^{\mathrm{a}}$ & $-1-$ \\
\hline 18 & POHS CNV & 42 & M & Fibrosis & - & $-/-$ & $-1-$ & $-1-$ & $-1-$ & $-1-$ & $-1-$ \\
\hline 19 & $\mathrm{PIC}$ & 27 & $\mathrm{~F}$ & Fibrosis & - & $-1-$ & $-1-$ & $-1-$ & $-1-$ & $-1-$ & $-1-$ \\
\hline 20 & UVEITIS & 20 & M & Fibrosis & - & $-1-$ & $-1-$ & $-1-$ & $-1-$ & $-1-$ & $-1-$ \\
\hline 21 & $\mathrm{CNV}$ & N.A. & N.A. & Fibrosis & - & $-1-$ & $-1-$ & $-1-$ & $-1-$ & $-1-$ & $-1-$ \\
\hline 22 & Myopic CNV & 55 & $\mathrm{~F}$ & Fibrosis & - & $-1-$ & $-/-^{\mathrm{a}}$ & $-/-^{a}$ & $-/-^{\mathrm{a}}$ & $-1-^{\mathrm{a}}$ & $-1-$ \\
\hline 23 & Myopic CNV & 41 & $\mathrm{~F}$ & Fibrosis & - & $-1-$ & $-/-$ & $-1-$ & $-/-$ & $-1-$ & $-1-$ \\
\hline 24 & Idiopathic CNV & 43 & $\mathrm{M}$ & Fibrosis & - & $-/-^{\mathrm{a}}$ & $-/-$ & $--^{\mathrm{a}}$ & $-1-$ & $--^{\mathrm{a}}$ & $-1-$ \\
\hline
\end{tabular}

$D S$ integrin marker and endothelial marker double staining, $P O H S$ presumed ocular histoplasmosis syndrome, $P I C$ punctate inner choroidopathy, $N . A$. not available in key

${ }^{\mathrm{a}} N=2$ (staining repeated twice on three sections per slide)

positively staining membranes for $\alpha v \beta 3, \alpha 1 \beta 1$, and $\alpha 2 \beta 1$ was observed. Similarly to active membranes, $50 \%$ of mid stage membranes stained positive for the $\alpha 5 \beta 1$ integrin, while nearly all membranes were positive for $\alpha \mathrm{v} \beta 5$ staining at this stage. The $\alpha \mathrm{v} \beta 5$ staining did not colocalize with endothelial cells. Integrin staining in late stage membranes was greatly reduced, with only the $\alpha v \beta 3$ and $\alpha v \beta 5$ staining being observed in a subset of samples. Staining for both endothelial cells and integrins was absent in fibrotic membranes, reflecting the acellular nature of the tissue.

These results indicate that expression of $\alpha v \beta 3$ and $\alpha v \beta 5$ observed in our study are similar to that observed by Friedlander et al. [9] with $\alpha \mathrm{v} \beta 3$ expression on endothelial cells and $\alpha \mathrm{v} \beta 5$ expression associated with nonendothelial cells. Temporally, pronounced $\alpha \mathrm{v} \beta 5$ staining occurred in mid and late stages, suggesting involvement during active remodeling and fibrotic stages, while $\alpha \mathrm{v} \beta 3$ is associated with mid and active stages of disease progression. In addition to characterization of $\alpha v \beta 3$ and $\alpha v \beta 5$, the current study extends our understanding of integrins involved in subretinal neovascularization by characterizing the pattern of expression for $\alpha 1 \beta 1, \alpha 2 \beta 1$, and $\alpha 5 \beta 1$.

Expression of $\alpha 1 \beta 1, \alpha 2 \beta 1$, and $\alpha 5 \beta 1$ integrin family members was present in association with endothelial cells in active membranes. However, in the mid stage tissues, $\alpha 5 \beta 1$ staining was more prevalent relative to that seen with either $\alpha 1 \beta 1$ or $\alpha 2 \beta 1$. This may reflect a higher expression level of $\alpha 5 \beta 1$ in newly forming vessels, as has been previously observed [11]. This suggests that during pathophysiological progression, expression of $\alpha 5 \beta 1$ is an early response associated with vessel invasion, while in later stages of disease progression, $\alpha 1 \beta 1$ and $\alpha 2 \beta 1$ may be important in matrix assembly and vessel morphology [12].

The association of $\alpha 1 \beta 1, \alpha 2 \beta 1$, and $\alpha v \beta 3$ with endothelial cells in AMD membranes is similar to that seen in dermal microvascular endothelial cells where the 
Fig. 2 Immunostaining for endothelial cell markers CD31 (a, $\mathbf{j}, \mathbf{m}$, and $\mathbf{p}$ ) or vWF (d and $\mathbf{g}$ ) and integrin staining $(\mathbf{b}, \mathbf{e}, \mathbf{h}, \mathbf{k}$, $\mathbf{n}$, and $\mathbf{q})$. The corresponding overlaid images of endothelial and integrin staining within a tissue are shown in $\mathbf{c}, \mathbf{f}, \mathbf{i}, \mathbf{l}, \mathbf{o}$, and $\mathbf{r}$, staining for $\beta 3$ integrin (b) showed colocalization with CD31 (a) as demonstrated by yellow signaling in c. Similar to the staining for $\beta 3$, staining for the heterodimer $\alpha \mathrm{v} \beta 3$ (e) with vWF (d) also demonstrated colocalization (f). The staining for $\alpha \mathrm{v} \beta 5$ (h) with vWF (g) showed limited colocalization with vWF (i). The majority of $\alpha v \beta 5$ staining (Cy3) localized outside of endothelial cells as identified by vWF staining (Alexa-488). Colocalization of integrin subunits $\alpha 1$ (k) with CD31 (j) as well as $\alpha 2(\mathbf{n})$ and $\alpha 5$ (q) with CD31 ( $\mathbf{m}$ and $\mathbf{p}$ ) is observed. Overlaid images for $\alpha 1$ and CD31 (I), $\alpha 2$ and CD31 (o), and $\alpha 5$ and CD31 (r). For all three integrin family members, staining was observed to colocalize with CD31 as well as to areas negative for the endothelial cell marker
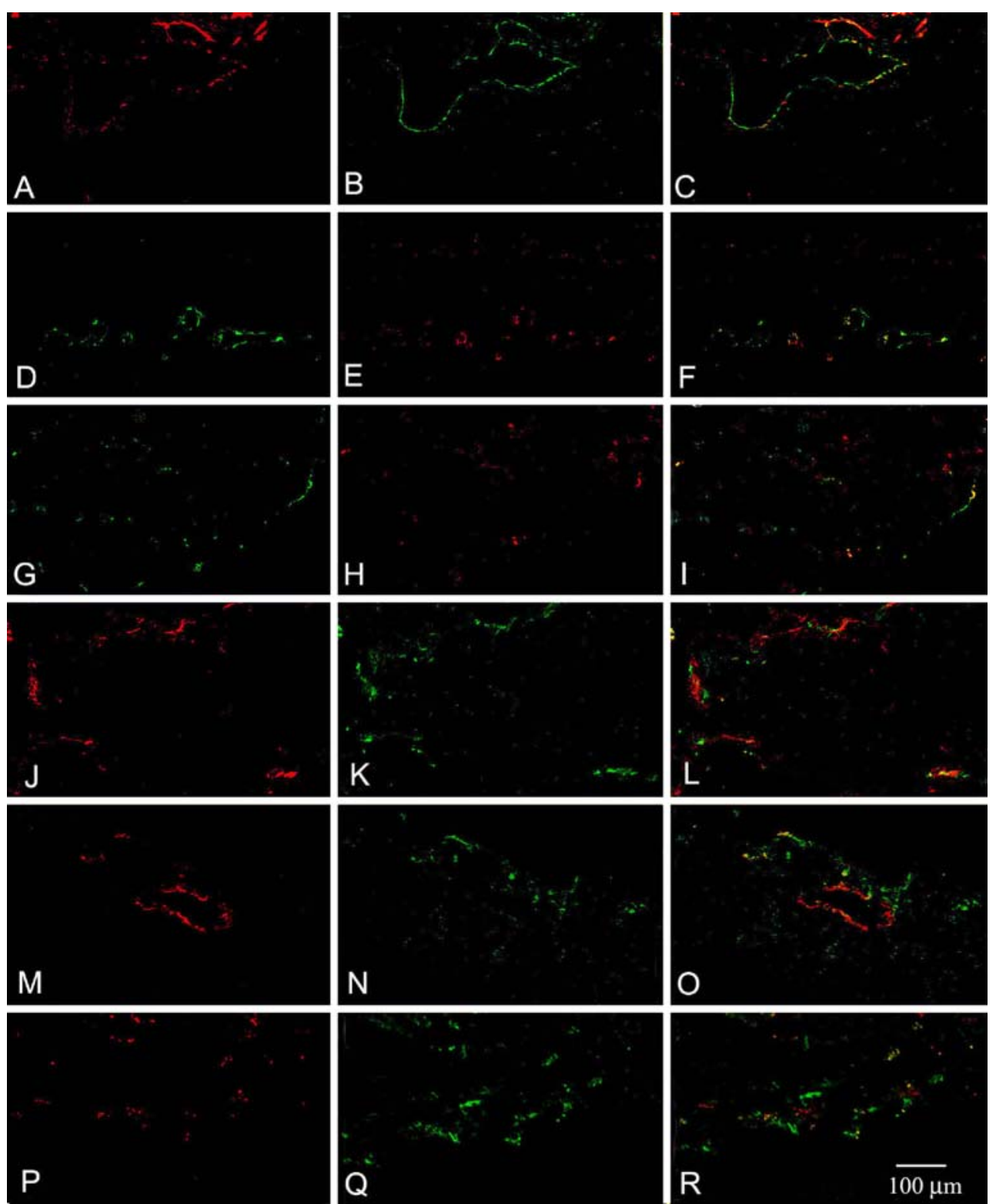

same three family members have been implicated in mediating the neovascular response [13]. Consistent with $\alpha 1 \beta 1$ and $\alpha 2 \beta 1$ expression is the presence of VEGF expression in AMD [14]. The exception to this correlation is that the most predominant family member expressed in neovascular membranes, $\alpha \mathrm{v} \beta 3$ integrin, has been characterized as associated with a bFGF-mediated and not a VEGF-driven angiogenic response [15]. However, the relationship between $\alpha \mathrm{v} \beta 3$ and bFGF is not obligatory with $\alpha v \beta 3$ expression correlating with a VEGF-induced neovascular response in a number of studies [16-19]. Furthermore, it has been demonstrated that $\alpha \mathrm{v} \beta 3$ plays a critical part in regulating VEGF-mediated signaling in endothelial cells [20-24]. The dynamic pattern of integrin expression seen is consistent with the complex nature of a neovascular response with temporal changes likely reflecting differing requirements in endothelial cell adhesion during a neovascular response $[11,25]$.

The data suggest that targeting $\alpha \mathrm{v} \beta 3$ provides the greatest potential as a selective therapeutic target present at all active stage of disease progression while targeting $\alpha 1, \alpha 2$, and $\alpha 5$ are both patient-restricted and stage-restricted. Blocking specific integrins, however, may not be sufficient as current studies targeting a single integrin $(\alpha \mathrm{v} \beta 3$ or $\alpha 5 \beta 1)$ have demonstrated only partial inhibition in CNV models [26, 27]. This may reflect overlapping and complementary functions between integrin family members expressed within a individual cell [4, 27], implicating that antagonism of multiple family members will be required to fully block a neovascular response [13]. In light of this complexity, greater 
efficacy in blocking angiogenesis may be achieved through strategies targeting functional regulation of multiple integrin family members as seen with endostatin and angiostatin [28] or by targeting the extracellular matrix [29-31]. Therapeutically, blocking a single integrin may provide a means to control various components of a subretinal neovascular response. As an example, inhibition of $\alpha \mathrm{v} \beta 3$ with cRGD has been observed to block VEGF-associated vascular blood-retinal barrier breakdown and cerebral edema [32]. While these data suggest $\alpha v \beta 3$ may be a candidate for therapeutic targeting, a more likely application of the observation is the potential use of $\alpha \mathrm{v} \beta 3$ as a marker of neovascular disease in poorly defined occult $\mathrm{CNV}$, using imaging techniques based on labeled RGD peptides [33].

Open Access This article is distributed under the terms of the Creative Commons Attribution Noncommercial License which permits any noncommercial use, distribution, and reproduction in any medium, provided the original author(s) and source are credited.

\section{References}

1. Hynes RO. Integrins: bidirectional, allosteric signaling machines. Cell 2002;1106:673-87.

2. Humphries JD, Byron A, Humphries MJ. Integrin ligands at a glance. J Cell Sci 2006;119Pt 19:3901-3.

3. Wu C, Hughes PE, Ginsberg MH, McDonald JA. Identification of a new biological function for the integrin alpha $\mathrm{v}$ beta 3 : initiation of fibronectin matrix assembly. Cell Adhes Commun 1996;43:149-58.

4. Hynes RO. A reevaluation of integrins as regulators of angiogenesis. Nat Med 2002;89:918-21.

5. Calderwood DA, Tai V, Di Paolo G, De Camilli P, Ginsberg MH. Competition for talin results in trans-dominant inhibition of integrin activation. J Biol Chem 2004;27928:28889-95.

6. Diaz-Gonzalez F, Forsyth J, Steiner B, Ginsberg MH. Trans-dominant inhibition of integrin function. Mol Biol Cell 1996;712:1939-51.

7. Eliceiri BP, Cheresh DA. Adhesion events in angiogenesis. Curr Opin Cell Biol 2001;135:563-8.

8. Esser P, Weller M, Heimann K, Wiedemann P. [Vitronectin and fibronectin receptors in proliferative retinal diseases]. Fortschr Ophthalmol 1990;874:344-7.

9. Friedlander M, Theesfeld CL, Sugita M, Fruttiger M, Thomas MA, Chang S, Cheresh DA. Involvement of integrins alpha v beta 3 and alpha $\mathrm{v}$ beta 5 in ocular neovascular diseases. Proc Natl Acad Sci U S A 1996;9318:9764-9.

10. Robbins SG, Brem RB, Wilson DJ, O'Rourke LM, Robertson JE, Westra I, Planck SR, Rosenbaum JT. Immunolocalization of integrins in proliferative retinal membranes. Invest Ophthalmol Vis Sci 1994;359:3475-85.

11. Zhang H, Li C, Baciu PC. Expression of integrins and MMPs during alkaline-burn-induced corneal angiogenesis. Invest Ophthalmol Vis Sci 2002;434:955-62.

12. Pozzi A, Moberg PE, Miles LA, Wagner S, Soloway P, Gardner HA. Elevated matrix metalloprotease and angiostatin levels in integrin alpha 1 knockout mice cause reduced tumor vascularization. Proc Natl Acad Sci U S A 2000;975:2202-7.

13. Perruzzi CA, de Fougerolles AR, Koteliansky VE, Whelan MC, Westlin WF, Senger DR. Functional overlap and cooperativity among alphav and betal integrin subfamilies during skin angiogenesis. J Invest Dermatol 2003;1206:1100-9.

14. Senger DR, Claffey KP, Benes JE, Perruzzi CA, Sergiou AP, Detmar M. Angiogenesis promoted by vascular endothelial growth factor: regulation through alpha1betal and alpha2beta1 integrins. Proc Natl Acad Sci U S A 1997;9425:13612-7.

15. Friedlander M, Brooks PC, Shaffer RW, Kincaid CM, Varner JA, Cheresh DA. Definition of two angiogenic pathways by distinct alpha v integrins. Science 1995;2705241:1500-2.

16. Walton HL, Corjay MH, Mohamed SN, Mousa SA, Santomenna LD, Reilly TM. Hypoxia induces differential expression of the integrin receptors alpha(vbeta3) and alpha(vbeta5) in cultured human endothelial cells. J Cell Biochem 2000;784:674-80.

17. Li SG, Ye ZY, Zhao ZS, Tao HQ, Wang YY, Niu CY. Correlation of integrin beta3 mRNA and vascular endothelial growth factor protein expression profiles with the clinicopathological features and prognosis of gastric carcinoma. World J Gastroenterol 2008;143:421-7.

18. Abumiya T, Lucero J, Heo JH, Tagaya M, Koziol JA, Copeland BR, del Zoppo GJ. Activated microvessels express vascular endothelial growth factor and integrin alpha(v)beta3 during focal cerebral ischemia. J Cereb Blood Flow Metab 1999;199:1038-50.

19. Rawlings NG, Simko E, Bebchuk T, Caldwell SJ, Singh B. Localization of integrin alpha(v)beta3 and vascular endothelial growth factor receptor-2 (KDR/Flk-1) in cutaneous and oral melanomas of dog. Histol Histopathol 2003;183:819-26.

20. Robinson SD, Reynolds LE, Wyder L, Hicklin DJ, HodivalaDilke KM. Beta3-integrin regulates vascular endothelial growth factor-A-dependent permeability. Arterioscler Thromb Vasc Biol 2004;2411:2108-14.

21. Liu ZJ, Snyder R, Soma A, Shirakawa T, Ziober BL, Fairman RM, Herlyn M, Velazquez OC. VEGF-A and alphaVbeta3 integrin synergistically rescue angiogenesis via N-Ras and PI3-K signaling in human microvascular endothelial cells. FASEB J 2003;1713:1931-3.

22. Masson-Gadais B, Houle F, Laferriere J, Huot J. Integrin alphavbeta3, requirement for VEGFR2-mediated activation of SAPK2/p38 and for Hsp90-dependent phosphorylation of focal adhesion kinase in endothelial cells activated by VEGF. Cell Stress Chaperones 2003;81:37-52.

23. Soldi R, Mitola S, Strasly M, Defilippi P, Tarone G, Bussolino F. Role of alphavbeta3 integrin in the activation of vascular endothelial growth factor receptor-2. EMBO J 1999;184:882-92.

24. Borges E, Jan Y, Ruoslahti E. Platelet-derived growth factor receptor beta and vascular endothelial growth factor receptor 2 bind to the beta 3 integrin through its extracellular domain. J Biol Chem 2000;27551:39867-73.

25. Chavakis E, Riecke B, Lin J, Linn T, Bretzel RG, Preissner KT, Brownlee M, Hammes HP. Kinetics of integrin expression in the mouse model of proliferative retinopathy and success of secondary intervention with cyclic RGD peptides. Diabetologia 2002;452:262-7.

26. Yasukawa T, Hoffmann S, Eichler W, Friedrichs U, Wang YS, Wiedemann P. Inhibition of experimental choroidal neovascularization in rats by an alpha(v)-integrin antagonist. Curr Eye Res 2004;285:359-66.

27. Meerovitch K, Bergeron F, Leblond L, Grouix B, Poirier C, Bubenik M, Chan L, Gourdeau H, Bowlin T, Attardo G. A novel RGD antagonist that targets both alphavbeta3 and alpha5beta1 induces apoptosis of angiogenic endothelial cells on type I collagen. Vascul Pharmacol 2003;402:77-89.

28. Sudhakar A, Sugimoto H, Yang C, Lively J, Zeisberg M, Kalluri R. Human tumstatin and human endostatin exhibit distinct antiangiogenic activities mediated by alpha v beta 3 and alpha 5 beta 1 integrins. Proc Natl Acad Sci U S A 2003;1008:4766-71.

29. Chavakis T, Cines DB, Rhee JS, Liang OD, Schubert U, Hammes HP, Higazi AA, Nawroth PP, Preissner KT, Bdeir K. Regulation of neovascularization by human neutrophil peptides (alpha-defen- 
sins): a link between inflammation and angiogenesis. FASEB J 2004;1811:1306-8.

30. Akalu A, Roth JM, Caunt M, Policarpio D, Liebes L, Brooks PC. Inhibition of angiogenesis and tumor metastasis by targeting a matrix immobilized cryptic extracellular matrix epitope in laminin. Cancer Res 2007;679:4353-63.

31. Cretu A, Roth JM, Caunt M, Akalu A, Policarpio D, Formenti S, Gagne P, Liebes L, Brooks PC. Disruption of endothelial cell interactions with the novel HU177 cryptic collagen epitope inhibits angiogenesis. Clin Cancer Res 2007;1310:3068-78.

32. Shimamura N, Matchett G, Yatsushige H, Calvert JW, Ohkuma H, Zhang J. Inhibition of integrin alphavbeta3 ameliorates focal cerebral ischemic damage in the rat middle cerebral artery occlusion model. Stroke 2006;377:1902-9.

33. Wu Y, Cai W, Chen X. Near-infrared fluorescence imaging of tumor integrin alpha v beta 3 expression with Cy7-labeled RGD multimers. Mol Imaging Biol 2006;84:226-36. 